\title{
УДК 327(73):351.746.1»20»
}

http://doi.org/10.17721/2521-1706.2016.02.38-47

Наталя Яковенко,

доктор історичних наук, професор, Київський національний університет імені Тараса Шевченка,

Галина Піскорська,

кандидат історичних наук, доцент, старший науковий співробітник, Київський національний університет імені Тараса Шевченка

\section{ПРІОРИТЕТИ МІЖНАРОДНО-ПОЛІТИЧНОЇ ДІЯЛЬНОСТІ США В СТРАТЕГІЯХ НАЦІОНАЛЬНОЇ БЕЗПЕКИ}

\begin{abstract}
Анотація. В статті детально розглянуто основні базові принципи сучасної зовнішньої політики Сполучених Штатів Америки, їх відображення в ключовому політичному документі офіційного Вашингтона - Стратегї національної безпеки. Зазначено, щзо Стратегія національної безпеки США $є$ набільш важсливим конщептуальним документом, згідно з яким здійснюється як зовнішня, так $і$ внутрішня політика країни. Наголошено, щуо особливістю Стратегій нащіональної безпеки США є їх глобальний характер, враховуючи той факт, щзо після Другої Світової війни Сполучені Штати Америки зайняли й нині продовжують зберігати позицію світового лідера та одного із головних иентрів сили на міжнародній арені. Проаналізовано еволюиію доктрини нащіональної безпеки США за діяльності президентських адміністраиій США Джорджа Бушамолодмого та Барака Обами у сфері безпеки, з'ясовано сутнісні зміни переходу від стратегій «жорсткої» до стратегій «м'якої» $i$ «розумної» сили. Конщепція «розумної сили», яка лежить в основі діяльності Адміністрації Барака Обами, сприяє усвідомленню та просуванню широкого спектра зовнішньополітичних иілей держави, зокрема, політики глобального лідерства, за допомогою поєднання дипломатичного, економічного і воєнного потенціалу.
\end{abstract}

Ключові слова: зовнішня політика США, глобальне лідерство, стратегії «жорсткої», «м'якої», «розумної» сили.

Стан міжнародної системи підтримання миру та стабільності - найважливіша спільна проблема сучасних міжнародних відносин в цілому й один 3 ключових параметрів оцінки ефективності зовнішньої політики будь-якої держави. Ефективність зовнішніх та внутрішніх безпекових стратегій держав залежить не тільки від того, якими зовнішньополітичними ресурсами володіє країна, а й від того, наскільки розумно вони використовуються. Найбільш значущим та узагальнюючим документом, що надає цілісну картину уявлення адміністрації США щодо зовнішньої політики країни, $є$ Стратегія національної безпеки США, що зумовлює підвищений інтерес до неї 3 боку багатьох зарубіжних і вітчизняних науковців, дослідження яких присвячено аналізу стратегій зовнішньої політики та безпеки США.

Аналіз зовнішньополітичних та безпекових стратегій представлено у загальних та спеціальних дослідженнях таких авторів, як: Дж. Най, Р. Армітідж, Зб. Бжезинський, Р. Кейган, Р. Кеохейн, А. Коен, У. Оуенс, Ф. Фукуяма, та ін.; серед вітчизняних науковців варто зазначити праці О. Бахтіярова, О. Бодрука, В. Головченка, А. Гуцала, Д. Дубова, О. Зернецької, С. Камінського, 
Б. Канцелярука, О. Литвиненка, С. Макаренко, С. Недбаєвського, М. Ожевана, І. Погорської, О. Потєхіна, Г. Почепцова, М. Рижкова, О. Сосніна, С. Федуняка, С. Шергіна, І. Хижняка, Л. Чекаленко, та ін.

Зазначимо, що уперше безпекову стратегію було представлено Адміністрацією Р. Ніксона, а 1986 року був прийнятий закон Голдуотера-Нікольса, за яким «Стратегія національної безпеки» стала обов'язковим документом для кожної нової адміністрації президента США. США будують свої стратегії на основі концепції беззаперечного i тотального домінування (лідерства) 3 позиції сили, яка грунтується на принципах абсолютної переваги у воєнній, технологічній, економічній, інформаційній сферах. У комплексі сучасних інструментів безпекової політики США також важливу роль відіграють невійськові засоби - економічні, фінансові, науково-технологічні, інформаційні, культурні та інші, які умовно об'єднані поняттям «м'який вплив», що суттєво розширює можливості країни виступати не тільки центром тяжіння для інших акторів міжнародних відносин, але й здійснювати на них ефективний несиловий тиск.

Як зазначають експерти, феномен сили у міжнародному середовищі - це насамперед здатність впливати на поведінку іншої держави в бажаному для себе напрямку, здатність встановлювати різні форми залежності однієї держави від іншої (прямі, непрямі, опосередковані, за допомогою насильства, переконання, обіцянки вигод, позбавлення наявних переваг, створення умов), в яких залишається лише одна альтернатива, один спосіб розв'язання суперечок, виходу із ситуації, що склалася. В цьому випадку очевидним стає той факт, що такий вплив може досягатися різними способами, а не тільки використанням військового потенціалу, військового тиску, загрози або ведення війни.

Саме досвід США у розробці та реалізації стратегій національної безпеки та зовнішньої політики $€$ найбільш показовим в даному контексті.

Найбільш гостро питання співвідношення застосування методів «м'якого» та «жорсткого» впливу у безпековій політиці постали за часів адміністрації Дж. Бушамолодшого в контексті проекту придушення «вісі зла», до якої увійшли переважно близькосхідні держави (Палестина, Сирія, Ліван, Йорданія, Єгипет, країни Аравійського півострова, Ірак, Іран). В рамках проекту пріоритетним напрямом було визначено нейтралізацію деспотичних $\mathrm{i}$ агресивних режимів, що загрожують миру $\mathrm{i}$ безпеці не тільки США, а й усього світу. В авторському вступі президента держави до Стратегії національної безпеки США 2006 р. 3 першого рядка зазначається, що Сполучені Штати знаходяться в стані війни: «Це стратегія воєнного часу обумовлена страшним викликом тероризму, який живиться від ідеології вбивства і ненависті, i який проявив себе повною мірою народу Сполучених Штатів в подіях 11 вересня 2001 року» [13]. Продовжується стратегія констатацією безпрецедентних можливостей Сполучених Штатів щодо закладання основ майбутнього миру через поширення лібералізму і демократії, як чинників миротворення у міжнародних відносинах. Задля реалізації цих можливостей треба обрати шлях впевненості й лідерства, відмовившись від трьох зол: ізоляціонізму, протекціонізму і пасивної оборони, зазначається у Стратегії.

Президент США визначає дві ключові мети політики національної безпеки США. Перша мета - це подолання тиранічних режимів і встановлення свободи, справедливості та поваги до людської гідності (з огляду на логіку документа автори Стратегії виходять із презумпції, що демократичні уряди ефективно управляють 
територіями, не утискають своїх громадян і не атакують інші нації). «Свобода найбільш надійна основа миру i міжнародної стабільності», - підкреслено в документі [13].

Другою ключовою метою Сполучені Штати вважають лідерство у спільноті демократичних націй, яка стає дедалі більшою. Багато наявних глобальних проблем - поширення пандемічних захворювань, тероризм, природні катастрофи потребують багатонаціональних зусиль для їхнього вирішення. «Америка повинна продовжити головування в світі» [13].

Документ чітко визначає завдання зовнішньої політики США: підтримувати рух на захист прав і гідності людини; зміцнювати коаліції для боротьби 3 тероризмом і працювати для запобігання атак на друзів і союзників; працювати 3 іншими для владнання регіональних конфліктів; не давати ворогам погрожувати нам, нашим друзям та союзникам зброєю масового знищення; розпочати нову еру глобального економічного зростання через вільні ринки і вільну торгівлю; поширити коло розвитку шляхом формування відкритих суспільств і побудови інфраструктури демократії; розробити порядок денний для кооперування з іншими основними центрами глобальної сили. Отже, стратегія національної безпеки виокремлює пріоритети державної політики у термінах політики та ії інструментів, які застосовуються для протидії принциповим загрозам національній безпеці США. Американська зовнішня політика, яка традиційно будувалася на поєднанні стратегій національної безпеки та глобальної демократизації, виявила нездатність сприяти реалізації амбіцій керівництва США за президентства Дж. Бушамолодшого, який, офіційно проголосивши в січні 2006 року концепцію «трансформаційної дипломатії», не зміг домогтися перетворення авторитарних режимів на стабільні демократії.

Реалізація нової концепції «розумної сили» США знайшла втілення у «Стратегії національної безпеки», яка була оприлюднена у травні 2010 р., і в якій визначено принципи обстоювання геополітичних інтересів Америки в сучасному світі. Суть нової консенсусної американської стратегії (розробники Дж. Най та Р. Армітідж) полягає у поєднанні «жорсткої» (воєнної) і «м’якої» (культурної) сили у спільну ефективну стратегію діяльності США на міжнародній арені задля повернення Америці статусу інтелектуального лідера та підтримання іміджу й репутації США на засадах ідеї «глобального добробуту» [11].

Водночас документ відзначається декларативним характером, містить дипломатичні формулювання, не розкриває багатьох аспектів реальної політики, проте «Стратегія національної безпеки» (2010) разом 3 іншими доктринальними документами («Чотирирічний огляд військової політики», «Огляд ядерної політики», «Огляд підходу до протиракетної оборони», «Стратегія у сфері кібербезпеки» тощо) подає достатньо розгорнуте уявлення про політичні пріоритети американського керівництва. Традиційно американський підхід до проблеми національної безпеки обмежувався міжнародними аспектами, оскільки вважалося, що питання внутрішньої політики та економічного розвитку не належать до сфери національної безпеки США, проте Адміністрація Б. Обами відійшла від такого жорсткого розмежування і розширила поняття національної безпеки [2].

Б. Обама підтримує ідею служіння історичній місії США - гарантуванню глобальної безпеки, але на відміну від попередників по Білому дому, Національна 
стратегія безпеки Б. Обами визнає цінність партнерства, надає більшого значення громадянському виміру на противагу військовому і підкреслює значення діалогу та необхідності зміцнення міжнародних інституцій.

Відтак, у документі, вважають політичні аналітики, що складається 3 52 сторінок, робиться спроба примирити ідеалізм кампанії Б. Обами з реальністю його конфронтації з неспокійним і небезпечним світом. У ньому описана Америка, «загартована війною» і «дисциплінована спустошливою економічною кризою», i зроблено висновок, що США не можуть нести тягар тривалих війн в Іраку й Афганістані, виконуючи при цьому й інші зобов'язання. Критики дорікали Б. Обамі в прагненні вибачатися за невдачі Америки і за готовність відмовитися від ролі єдиної супердержави. «Але для команди Б. Обами це документ, який бачить світ таким, яким він $\epsilon$, і знаменує кінець епохи ілюзій, коли Вашингтон вбачав переваги застосування «жорсткої» сили у досягненні результатів» [4].

«Стратегія національної безпеки» містить низку важливих новацій тактичного i стратегічного характеру: зокрема, вперше в стратегії пропонується інтегрувати основні інструменти американської потужності - дипломатію, військову силу, економічні інструменти, розвідку; сили забезпечення внутрішньої безпеки [7]. Крім того, аналіз документа дозволяє виділити й чотири стратегічні аспекти: безпеку; економічне процвітання; просування «універсальних цінностей»; зміцнення світопорядку за умови американського лідерства у вирішенні важливих міжнародних проблем. Стратегія мала всеосяжний характер i була спробою інтегрувати внутрішні та міжнародні аспекти національної безпеки з огляду на те, що найгостріша системна криза спричиняє «перевантаження» сил Америки у спробі консолідувати однополярний світ, оскільки жодна країна не в змозі повністю забезпечувати міжнародну відповідальність.

Проблема внутрішньої безпеки в документі стосується відновлення американської економіки (вперше до сфери національної безпеки віднесене завдання збільшити американський експорт в 2 рази до 2014 року і частку капіталів

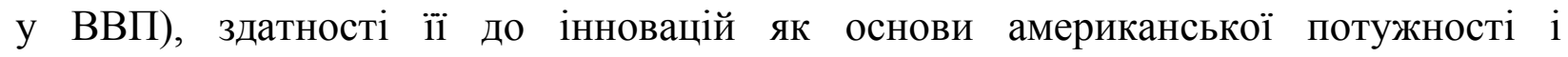
конкурентоспроможності, вирішення проблеми дефіциту державного бюджету [1]. Особливий наголос зроблено на проблемах розвитку освіти, охорони здоров'я, науки і техніки. Відтак, йдеться про підвищення інтелектуального потенціалу США за рахунок «повної освіти всього американського населення» і збільшення до 2020 року відсотка осіб з вищою освітою. Враховуючи інтелектуальну складову «м'якої сили», «Стратегія національної безпеки» розглядала науково-технологічні досягнення як інструмент забезпечення пріоритетів безпеки США, у тому числі мала на меті захистити американські війська від асиметричних інформаційних атак; забезпечити виконання угод про контроль над новітніми озброєннями та їх нерозповсюдженням; запобігти терористичним нападам на території США; попередити i зупинити розповсюдження епідемій; захистити інформаційну інфраструктуру, засоби транспорту і зв'язку.

У документі наголошується і на провідній ролі військового чинника, тобто «жорсткої сили», у стратегії безпеки, оскільки США мають намір зберігати військове лідерство і здатність до протидії загрозам будь-якого потенційного супротивника Таким чином, у стратегії не знято повністю тезу про право Вашингтона на «жорстку силу», тобто односторонні військово-силові дії за вибором США: «Коли використані всі інші методи, застосування сили іноді стає 
необхідним. До ведення війни ми ретельно зважимо вартість і ризики дії i бездіяльності ... Ми будемо прагнути до широкої міжнародної підтримки, зокрема, таких інститутів, як НАТО і Рада Безпеки ООН. США зберігають право на односторонні дії, якщо необхідно захистити нашу країну і наші інтереси, але ми будемо прагнути дотримуватися норм, що регулюють застосування сили» [10].

Документ подає бачення Адміністрації Б. Обами щодо ролі США у поліцентричній системі міжнародних відносин, яким проголошується пріоритет колективних дій світової спільноти в рамках міжнародного права, підкреслюється необхідність зміцнення міжнародних інститутів, декларується визнання прав та обов'язків всіх держав щодо прогресивного розвитку людства, акцентується необхідність взаємодії з американськими союзниками - країнами НАТО, зокрема 3 Великою Британією, Францією, Німеччиною, а також 3 Японією, Південною Кореєю, Австралією тощо. Особливу увагу у стратегії Б. Обами звернуто на те, що у світі зростає кількість нових «центрів впливу», 3 якими США необхідно взаємодіяти. Серед таких центрів розглядаються Китай, Індія, Росія і регіональні «центри впливу» - Бразилія, Індонезія, Південна Африка, Саудівська Аравія, Нігерія, Кенія.

Стратегія відзначає «дифузію економічної потужності в світі», що передбачає вирішення глобальних фінансово-економічних проблем за допомогою не тільки «великої вісімки» (сім західних країн і Росія), а й «великої двадцятки», куди входять майже всі нові «центри впливу». Це означає, що Вашингтон переходить від стратегії «єдиної наддержави» в однополярному світі до стратегії забезпечення лідерства США в поліцентричній системі міжнародних відносин [8]. Згаданий документ здатний викликати критику щодо зміни курсу американської зовнішньої політики останнього часу, готовності відмовитися від ролі єдиної супердержави, але для команди Б. Обами це документ, який знаменує відмову від доктрини «стримування» на користь доктрини «розумної сили» [6; 9; 5].

Водночас, нова Стратегія приділяє увагу тим аспектам безпеки держави, яким у попередніх Стратегіях не було приділено суттєвого значення.

У «Стратегії національної безпеки» (2010р.) проблема захисту кібермереж згадується поряд 3 проблемою захисту США від біологічних атак, а ступінь проникнення кібермереж у життя американського суспільства визначається як «залежність» від них, оскільки «космос та кіберпростір мають силу впливати на повсякденне життя та військові операції». Крім того, кібератаки віднесені до однієї 3 ключових проблем у внутрішній безпеці США: «Всередині країни США будуть прагнути стратегії, спроможної протидіяти всьому спектру загроз і небезпек для нашого суспільства. Це загрози та небезпеки, що включають в себе тероризм, стихійні лиха, масштабні кібератаки і пандемії». Загалом, роз'ясненню позиції Адміністрації Б. Обами щодо безпеки кіберпростору у новій Стратегії надано окремий параграф «Безпека кіберпростору», де зазначено, що загрози в сфері кіберпростору $\epsilon$ однією 3 найбільших загроз національній, суспільній та економічній безпеці, 3 якими зіткнулись США: «Високий рівень нашої технологічності, що дозволяє нам існувати та створювати, водночас надає додаткові можливості для тих, хто хоче підірвати наші можливості або знищити їх». Ця ж «технологічність» дає збройним силам США значну перевагу, однак не убезпечує несекретні урядові мережі від постійного несанкціонованого втручання.

Як свідчить аналіз, у «Стратегії національної безпеки» традиційно присутня 
проблема захисту демократії i прав людини: по-перше, наголошується, що необхідно насамперед дотримуватися захисту прав людини у США; по-друге, вперше відзначається важливе значення економічних і соціальних прав і свобод, подолання бідності; по-третє, стверджується, що США не нав'язуватимуть свою модель демократії, а будуть спиратися на «силу прикладу» і вести діалог з питань прав людини навіть 3 «недемократичними режимами». Отже для Адміністрації Б. Обами пріоритетною є стратегія «розумної сили», яка охоплює дипломатію, національні цінності, науково-технологічні інновації та безпеку, що свідчить про політичне прагнення США підтримати міжнародний порядок, здатний вирішити глобальні проблеми.

У лютому 2015 р. в США прийнята нова редакція Стратегії національної безпеки [14]. В доповіді Президента сформульовано підходи Адміністрації Б. Обами щодо політичних, оборонних, економічних та інших аспектів забезпечення безпеки та добробуту Сполучених Штатів, адаптовані до наявних та потенційних загроз i викликів. Згідно $з$ усталеною практикою, положення оновленої Стратегії сприятимуть відповідним змінам в міжнародному курсі Вашингтона, що спрямований на найбільш ефективне просування американських інтересів за кордоном на регіональному та глобальному рівнях. Пропонується широка програма взаємодії з оточуючим світом у його сучасному стані. У документі прагнення до зміни світового порядку за допомогою сили поступається усвідомленню глобальної ролі Росії та виходу на світову арену таких держав, як Китай та Індія. Зовнішню політику США планується адаптувати до нових еволюціонуючих загроз, включаючи кібервійни, епідемічні захворювання, етнічні конфлікти тощо.

В якості основної гарантії збереження впливу США у світі, як і раніше, розглядаються міцні та боєздатні військові сили попри тези про необхідність використання комплексного підходу щодо забезпечення безпеки держави, який передбачає постійне сполучення політико-дипломатичних, військових, економічних, ідеологічних та інших інструментів впливу на оточення.

У вступній частині документа стверджується, що всередині американської політичної еліти існує консенсус щодо світового лідерства США. Саме тут визначені цілі лідерства або національні інтереси:

- «безпека Сполучених Штатів, їх громадян, а також американських союзників та партнерів;

- міцна інноваційна та зростаюча національна економіка, яка функціонує в межах відкритої міжнародної економічної системи та сприяє процвітанню держави;

- повага до універсальних цінностей всередині держави та за кордоном;

- заснований на першості Закону світопорядок, забезпечений провідною роллю США та спрямований на підтримання безпеки, нарощування можливостей реагування на глобальні виклики через тісніше міжнародне співробітництво».

Автори документа також вважають, що «Сполучені Штати забезпечуватимуть своє лідерство, виступаючи прикладом для інших держав». Тобто, «міцність американських інститутів влади, наша прихильність до верховенства Закону $є$ наочними прикладами для всіх демократичних урядів. Якщо ми наполегливо відстоюємо свої цінності у себе вдома, то будемо здатними ефективніше просувати їх за кордоном. Дотримання міжнародних норм та стандартів дозволяє очікувати аналогічних дій з боку інших держав» [14]. 
США мають намір забезпечувати стримування агресії Росії, уважно спостерігати за ¥ї стратегічними можливостями та допомагати союзникам та партнерам чинити опір тиску з боку Росії в довгостроковій перспективі в разі необхідності. В 2015 р. в бюджеті США були враховані витрати для боротьби проти «тиску Росії». В своєму бюджетному посланні Б. Обама заявив, що у відповідь на агресивні дії з боку Російської Федерації в бюджеті містяться пропозиції щодо політичної, економічної та військової підтримки союзників по НАТО та держав-партнерів у Європі. Б. Обама зазначив, що США підтримуватимуть уряди держав, що опинилися «головними мішенями тиску» 3 боку Росії. Водночас «двері залишатимуться відкритими» для можливості подальшого співробітництва з Росією в сферах спільних інтересів, якщо вона обере інший шлях - шлях мирного співробітництва при повазі суверенітету та демократичного розвитку сусідніх держав.

«Агресія Росії в Україні дала ясно зрозуміти, що європейська безпека i міжнародні правила і норми, спрямовані проти територіальної агресії, не можуть прийматися на віру. У відповідь ми домоглися міжнародних зусиль в підтримку українського народу, який зробив вибір свого майбутнього i розвиває власну демократію і економіку», - зазначено у тексті Стратегії національної безпеки [14].

Втім впливовий аналітичний центр Council on Foreign Relations (CFR) у 2016 році понизив свою оцінку пріоритетності попередження конфлікту в Україні для закордонної політики США у доповіді «Дослідження превентивних пріоритетів-2016» [12]. Дослідники центру CFR віднесли конфлікт в Україні до другої за важливістю групи тривожних ситуацій у світі, попередження яких мало би стати пріоритетом для американських дипломатів. Натомість до пріоритетних завдань закордонної політики США експерти центру віднесли: громадянську війну у Сирії; напад із масовими жертвами на США, або їх союзника; конфлікт 3 Північною Кореєю, або в ній самій внаслідок випробування КНДР ядерної, чи балістичної зброї; політичну нестабільність ЄС; роздроблення Лівії; конфлікт між Ізраїлем та Палестинськими територіями; політичне насильство у Туреччині; нестабільність в Сгипті; нестабільність та насильство в Афганістані; подальше дроблення Іраку.

Керівництво США взяло на себе зобов'язання підтримувати міжнародну стабільність, колективні зусилля міжнародного співтовариства в боротьбі проти тероризму, передусім проти Аль-Каїди, ІДІЛ, за заборону доступу терористів до ядерних матеріалів, в боротьбі проти розповсюдження зброї масового знищення, мобілізовувати зусилля світового співтовариства, спрямовані на пом'якшення негативних наслідків кліматичних змін та можливостей виникнення небезпечних хвороб. У вирішенні цих завдань головну роль мають відігравати збройні сили, оскільки вони «зберігатимуть здатність протидіяти будь-яким загрозам, включаючи галузь протиракетної оборони, кібербезпеки, боротьби проти тероризму, стримування агресії та ліквідації наслідків стихійних лих. США зберігатимуть військову присутність за кордоном для захисту американських громадян i їх інтересів, підтримання регіональної стабільності, надання гуманітарної допомоги та для нарощування потенціалу іноземних партнерів, необхідного при проведенні спільних операцій» [14].

Проте застосування сили не є єдиним ефективним засобом протидії викликам або засобом забезпечення залучення США до глобальних акцій. Навпаки, 
пріоритетними інструментами в даній галузі $є$ дипломатія, а також вибіркове застосування економічних санкцій, яке залишатиметься ефективним засобом впливу на безвідповідальних суб'єктів міжнародних відносин, а також ліквідація кримінальних і терористичних мереж.

Лідерство США спирається на надійних партнерів. «Ми послідовно поширюватимемо рамки взаємодії з іншими країнами, недержавними суб' єктами та міжнародними інститутами - передусім ООН, транснаціональними фінансовими структурами, регіональними організаціями. Це може надати значного імпульсу щодо збільшення спільного внеску учасників на підтримку глобальної безпеки та процвітання, дотримання норм відповідальної поведінки на міжнародній арені» [14].

США забезпечуватимуть своє лідерство із розрахунком на довгострокову перспективу. Так само, як в минулому столітті Сполучені Штати сприяли розвиткові світових процесів, на сьогодні вони зобов'язуються впливати на їхній хід та характер, удосконалюючи засоби та форми впливу для утримання свого лідерства. Згідно Стратегії, Вашингтон несе відповідальність щодо забезпечення енергетичної безпеки своїх союзників в Європі та інших регіонах світу. «Виклики, обумовлені українською та європейською залежністю від постачання російських енергоресурсів, наочно демонструють необхідність розробки нових підходів до проблеми забезпечення енергетичної безпеки, враховуючи колективні потреби Сполучених Штатів, наших союзників та торговельних партнерів, а також важливість розвитку інших конкурентоздатних ринків» [14].

Вашингтон бере на себе ще одне зобов’язання - «очолювати процес адаптації, формування i, коли дозволяють обставини, запровадження правил та норм, створення інститутів, які $є$ базовою основою для миру, безпеки, добробуту та захисту прав людини у XXI столітті». В цьому зв'язку Сполучені Штати продовжуватимуть пошук раціональних рішень по всіх пріоритетних напрямках реалізації зовнішньополітичного курсу, застосовуючи необхідні дипломатичні та інші інструменти.

В якості держави, що утворила глобальну інформаційну мережу, Сполучені Штати також несуть особливу відповідальність за підтримання лідерства в рамках «кібернетичного миру», забезпечення безпеки космічного простору (повинні «разом протидіяти загрозам з боку тих, хто прагне не допустити мирного використання космосу»), а також повітряного та морського простору.

Вітчизняні аналітики зазначають, що особливістю Стратегій національної безпеки США є їх глобальний характер, враховуючи той факт, що після Другої Світової війни Сполучені Штати зайняли позицію світового лідера та одного із центрів сили на міжнародній арені [3]. Крім цього, Стратегія національної безпеки США (особливо, в останні роки) є основним концептуальним документом, згідно 3 яким здійснюється як зовнішня, так і внутрішня політика країни. Нова стратегія Б. Обами має всеосяжний характер і $є$ спробою інтегрувати внутрішні та міжнародні аспекти національної безпеки з огляду на те, що найгостріша системна криза свідчить про перевантаження сил США у спробі консолідувати однополярний світ, оскільки жодна країна не в змозі забезпечувати повну міжнародну відповідальність. У політичному протиборстві за лідерство у світовому співтоваристві вагому роль відіграють стратегї̈ «м'якої сили», які розглядаються як державні документи, що мають водночас історичну і політичну значимість, оскільки упродовж їх здійснення вони 
зазнають конструктивних змін (від стратегій «жорсткої» до стратегій «м'якої» i «розумної» сили), зумовлених новими викликами і загрозами для міжнародної стабільності і миру.

Концепція «розумної сили», яка лежить в основі діяльності Адміністрації Б. Обами, сприятиме, на думку провідних політологів США, просуванню широкого спектра зовнішньополітичних цілей держави, зокрема, політики глобального лідерства, за допомогою поєднання дипломатичного, економічного і воєнного потенціалу. Ідеологія «розумної сили», на наш погляд, сповідує головний імператив діяльності США на міжнародній арені: захист національних інтересів у якісно новому контексті зовнішньополітичних впливів.

\section{Література}

1. Введение президента Обамы к Отчету о стратегии национальной безопасности (28 мая 2010 года). [Електронний ресурс]. - Режим доступу: http://www.america.gov/st/peacesec-russian/2010/May/20100528114736ejavosson0.5478632.html.

2. Дулейран Ю. У США оприлюднили нову стратегію національної безпеки / Ю. Дулейран. [Електронний ресурс $]$ - Режим доступу: http://www.radiosvoboda.org/content/article/2054788.html.

3. Концептуальні засади розвитку системи забезпечення національної безпеки України: аналіт. доп. / О. О. Резнікова, В. Ю. Цюкало, В. О. Паливода, С. В. Дрьомов, С. В. Сьомін. - К.: НІСД, 2015. $-58 \mathrm{c}$.

4. Макаренко Є. А. Ризики і перспективи політики безпеки адміністрації США в умовах «перезавантаження» міжнародних відносин / С. А. Макаренко // Актуальні проблеми міжнародних відносин. (Інститут міжнародних відносин Київського національного університету імені Тараса Шевченка). - К., 2010. - Вип. 94. - Ч. І. - С. 11-16.

5. Нова стратегія безпеки США в баченні Обами. [Електронний ресурс] - Режим доступу: http://otherside.com.ua/news/ detail.php?lang=1\&id=83241.

6. Обама відмовляється від ролі «світового жандарма». [Електронний ресурс]. - Режим доступу: http://www.newsru.ua/press/28may2010/obama.html.

7. Обама добивается безопасности путем мира и сотрудничества (27 мая 2010 года). [Електронний peсурс]. - Режим доступу: http://www.america.gov/st/ peacesecrussian/2010/May/20100528130723arrrud0.915127.html.

8. Рогов С. Американское лидерство в многополярном мире. Основы «Стратегии национальной безопасности» Обамы. / С. Рогов. [Електронний ресурс] - Режим доступу: http://www.centrasia.ru/ newsA.php?st=1276462800.

9. У США нова стратегія безпеки. [Електронний ресурс]. - Режим доступу: http://www.unian.net/ukr/news/news-378925.html.

10. Шамшур О. Початок ери Обами. Зовнішньополітичний вимір / О. Шамшур. [Електронний ресурс] - Режим доступу: http://www.zn.ua/1000/1550/64642.

11. Nye J. S. A smarter, more secure America. Report of the CSIS Commission on Smart Power / Craig Cohen, Joseph S. Nye, Richard Armitage. [Електронний ресурс]. - Режим доступу: $\mathrm{http}: / /$ csis.org/publication/smarter-more-secure-america.

12. The Council on Foreign Relations (CFR):Preventive Priorities Survey: 2016. [Елекроннийресурс]. - Режим доступу: http://www.cfr.org/conflict-assessment/preventive-priorities-survey-2016/p37364.

13. The National Security Strategy of the United States of America (2006). [Електронний pecypc]. - Режим доступу : http://www.presidentialrhetoric.com/speeches/nss2006.pdf.

14. The National Security Strategy of the United States of America (2015). [Електронний pecypc]. Режим https://www.whitehouse.gov/sites/default/files/docs/2015_national_security_strategy.pdf. доступу:

Надійшла до редколегії 07.07.2016 
Natalya Yakovenko, Dr. Sc., Professor, Taras Shevchenko National University of Kyiv, Kyiv, Ukraine.

Galyna Piskorska, Ph.D. in History, Senior Researcher, Taras Shevchenko National University of Kyiv, Kyiv, Ukraine.

PRIORITIES OF INTERNATIONAL POLITICAL ACTIVITIES IN US NATIONAL SECURITY STRATEGIES

Abstract. The article deals with the basic principles of US contemporary foreign policy, their reflection in the key political document - National Security Strategy. It is mentioned that the US National Security Strategy is the main conceptual document according to which both internal and foreign policy of the state is pursued. It is stressed that the particular feature of the US National Security Strategies is their global nature considering that the US gained a position of a world leader and one of the centers of power at the international scene after the Second World War. Evolution of the US National Security Doctrine has been analyzed during activities of US presidential administrations of G. Bush Junior and B. Obama in the sphere of national security, essential changes from "hard» to "soft» and "smart» power have been interpreted. Smart power means developing an integrated strategy, resource base, and tool kit to achieve American objectives, drawing on both hard and soft power. The concept of «smart power» being the basic one for B. Obama's Administration, is aimed at reaching a wide range of purposes of American foreign policy, global leadership in particular, while combining diplomatic, economic and military potentials. By complementing U.S. military and economic might with greater investments in soft power, America can build the framework it needs to tackle tough global challenges.

Key words: US foreign policy, strategies of «hard», «soft» and «smart» power 